\title{
Apakah saliensi mortalitas berperan dalam menjelaskan prasangka terhadap pasangan antarbudaya? Sebuah studi eksperimental
}

\author{
Yurik Yang \& Dicky C. Pelupessy* \\ Fakultas Psikologi, Universitas Indonesia, Depok
}

\begin{abstract}
Abstrak
Studi Terror Management Theory (TMT) selama ini telah menunjukkan bahwa mengingatkan seseorang mengenai kematian (saliensi mortalitas) dapat membuatnya lebih berprasangka. Namun, masih belum jelas apakah sikap berprasangka tersebut juga dapat menyasar terhadap pasangan antarbudaya. Untuk itu, studi ini dilakukan guna menguji peran kecemasan eksistensial dalam kemunculan prasangka terhadap pasangan antarbudaya dengan menggunakan desain faktorial antarsubjek 2 (SM vs. kontrol) x 2 (harga diri tinggi vs. rendah). Partisipan penelitian ini terdiri dari 104 mahasiswa. Hasil studi menunjukkan bahwa partisipan yang diminta untuk memikirkan mengenai kematian memiliki skor rata-rata evaluasi terhadap pasangan antarbudaya yang secara signifikan lebih rendah dibandingkan partisipan yang diminta untuk memikirkan mengenai topik netral. Hasil studi ini memberikan bukti preliminer mengenai adanya peran kecemasan eksistensial di balik kemunculan prasangka terhadap pasangan antarbudaya.
\end{abstract}

Kata kunci: harga diri, pasangan antarbudaya, prasangka, saliensi mortalitas, terror management theory

\begin{abstract}
Terror Management Theory (TMT) studies over three decades have provided important information regarding the role of mortality reminders on prejudicial attitudes towards the outgroup members. Exposure to mortality reminders (mortality salience) has been shown to intensify one's prejudicial attitudes and behaviors. However, the extent to which such effect could generalize towards intercultural couples is still unclear and understudied. The present study was conducted to examine whether mortality reminders would increase prejudicial attitudes towards intercultural couples. A total of 104 undergraduate students participated in a 2 (mortality salience vs. control) x 2 (low vs. high self-esteem) between-subject factorial design experimental study. Compared to participants in the control group, participants in the mortality salient condition reported a significantly lower evaluation towards intercultural couples. The empirical finding of this study provided preliminary evidence for the role of existential concern on prejudicial attitudes towards intercultural couples.
\end{abstract}

Keywords: intercultural couples, mortality salience, prejudice, self-esteem, terror management theory

\section{Pendahuluan}

Pasangan antarbudaya seringkali menjadi korban prasangka, seperti menerima tatapan dingin atau ujaran kebencian bahkan dari orang yang sama sekali tidak dikenal (Biever, Bobele, \& North, 1998). Adanya prasangka terhadap pasangan antarbudaya diperkuat dengan tiga bukti yakni: (1) adanya penolakan kehadiran pasangan ini secara eksplisit (Djamba \& Kimuna, 2014); (2) adanya bias implisit (Skinner \& Hudac, 2017); dan (3) adanya bias afektif (Skinner \& Rae, 2018).

Naskah masuk: 24 Agustus 2019

Naskah diterima: 30 Mei 2020
Adanya penolakan secara terbuka, rasa jijik, dan bias implisit dapat berujung pada perlakuan diskriminatif dan perundungan terhadap pasangan antarbudaya. Perundungan tersebut sering muncul di media sosial dalam bentuk hujatan dan penghakiman massal yang menyasar pasangan antarbudaya. Pasangan antarbudaya sering menerima ujaran kebencian bahkan dari pihak yang tak dikenal dan tanpa sebab yang jelas. Pada suatu kasus, sebuah unggahan video daring yang menampilkan pernikahan pasangan antarbudaya dihujani dengan makian oleh sebagian netizen.

* Fakutas Psikologi, Universitas Indonesia Kampus UI, Depok, Jawa Barat, Indonesia, 16424 E-mail: dickypsy@ui.ac.id 
Pada laman komentar video tersebut, sebagian netizen mengeluarkan kata-kata kasar dan hinaan rasialis yang menyasar identitas etnis kedua pasangan tersebut. Kasus ini hanya merupakan contoh kecil dari berbagai manifestasi sikap antipati yang menyasar pasangan antarbudaya.

Prasangka terhadap pasangan antarbudaya juga sebenarnya bukan hal yang baru. Secara historis, beberapa etnis di Indonesia melarang adanya hubungan romantis antarbudaya (Yulianto \& Faturochman, 2017). Prasangka terhadap pasangan antarbudaya juga tidak hanya terjadi di Indonesia misalnya, larangan pernikahan antarras pada masa apartheid di Afrika Selatan. Mengingat keuniversalan dari fenomena ini, maka studi ini berargumen bahwa kemunculan prasangka tersebut tidak dapat dipisahkan dari peran budaya sebagai komponen peredam kecemasan eksistensial manusia.

Melalui perspektif TMT, prasangka dipandang sebagai salah satu perwujudan dari upaya manajemen kecemasan eksistensial yang dilakukan manusia secara tidak sadar dengan cara menyerang segala ancaman bagi pandangan dunia kultural yang ia anut. Kehadiran pasangan antarbudaya mungkin dianggap sebagai ancaman terhadap pandangan dunia kultural bagi sebagian orang sehingga menimbulkan reaksi defensif berupa prasangka. Beberapa pihak mungkin menganggap kehadiran pasangan antarbudaya sebagai ancaman pandangan dunia kultural karena kehadiran pasangan ini mencerminkan adanya ketidakpatuhan pada norma kelompok. Ketidakpatuhan pada norma kelompok tersebut dapat mengancam validitas konsensus pandangan dunia kultural dan memicu reaksi defensif dari anggota kelompok yang bersangkutan (Arndt, Greenberg, Schimel, Pyszczynski, \& Solomon, 2002; Frischlich, Rieger, Dratsch, \& Bente, 2015). Reaksi defensif ini dapat menjadi akar dari adanya prasangka terhadap kehadiran pasangan antarbudaya. Riset sebelumnya telah mengidentifikasi efek saliensi mortalitas dalam TMT terhadap prasangka. Namun, masih belum jelas apakah efek itu bisa digeneralisasi dalam konteks prasangka terhadap pasangan antarbudaya.

\section{Teori manajemen teror: Bagaimana ancaman kematian dikelola secara psikis}

Terror management theory, yang biasa disingkat TMT (Greenberg, Pyszczynski, \& Solomon, 1986; Pyszczynski, Solomon, \& Greenberg, 2015) dapat menjadi dasar teoretis yang kuat untuk menjelaskan fenomena prasangka terhadap pasangan antarbudaya. Menurut TMT, berkembangnya kesadaran diri (self-awareness) dan kemampuan kognitif kompleks lainnya, membuat manusia tersadar akan realitas kefanaan dirinya. Untuk menghadapi kondisi ini, suatu sistem manajemen teror kematian telah berkembang dalam diri manusia yang bekerja secara tidak sadar untuk mengendalikan kecemasan eksistensial-yakni kecemasan akan kefanaan kehidupan dan kepastian kematian-dan menjaga ketenangan psikologis manusia (psychological equanimity).

Sistem manajemen teror kematian manusia menurut Greenberg, Pyszczynski, dan Solomon (1986) tersusun dari dua komponen utama, yaitu pandangan dunia kultural (cultural worldview) dan harga diri (self-esteem). Pandangan dunia kultural merupakan ide-ide mengenai realitas yang dianut manusia karena dapat memberikan struktur, stabilitas dan makna bagi kehidupan misalnya, ideologi, keyakinan, budaya, dan sebagainya (Pyszczynski dkk., 2015). Pandangan dunia kultural memungkinkan adanya konsepsi mengenai realitas yang dapat memberikan rasa kebermaknaan dalam kehidupan seperti memberikan jawaban terhadap pertanyaan kosmologis (misalnya arti kehidupan) dan menyediakan struktur yang mengorganisasi persepsi manusia (misalnya konsep waktu) (Greenberg, Solomon, \& Pyszczynski, 1997). Identitas etnis atau kesukuan merupakan salah satu bentuk dari pandangan dunia kultural. Identitas etnis memberikan manusia berbagai narasi yang memungkinkan penciptaan makna bagi kehidupan seperti penjelasan mengenai asal usul, standar nilai, struktur sosial hingga menyediakan sarana untuk mencapai keabadian (immortality). Dengan memenuhi standar nilai pada suatu pandangan dunia kultural, manusia menjadi berhak untuk memperoleh keabadian, baik keabadian secara simbolis (misalnya dikenang setelah meninggal dunia) maupun harfiah (misalnya masuk surga).

Tetapi, TMT menilai bahwa pandangan dunia kultural merupakan hasil konstruksi sosial yang bersifat rapuh dan terus-menerus membutuhkan konsensus antarmanusia guna mempertahankan validitasnya (Greenberg dkk., 1997). Adanya ketidakpatuhan terhadap nilai pandangan dunia kultural dapat berakibat fatal bagi kedamaian psikologis manusia yang menganutnya karena dapat menyangkal kebenaran dari suatu pandangan dunia kultural tertentu. Akibatnya, manusia cenderung bereaksi defensif terhadap segala hal yang-baik secara langsung maupun tidak langsung-mengancam validitas pandangan dunia kultural mereka. Kehadiran individu atau kelompok yang menganut pandangan dunia kultural yang berbeda dapat secara tidak langsung mengancam validitas pandangan dunia kultural individu lain karena dapat membuat individu tersebut mempertanyakan validitas dari pandangan dunia kulturalnya sendiri (Abdollahi, Henthorn, \& Pyszczynski, 2010; Greenberg dkk., 
1997; Harmon-Jones, Greenberg, Solomon, \& Simon, 1996).

Adanya ancaman terhadap validitas suatu pandangan dunia kultural dapat menimbulkan kecemasan (anxiety) bagi individu yang menganut pandangan dunia kultural tersebut (Juhl \& Routledge, 2016). Kecemasan timbul karena individu menjadi tersadar (salient) akan sifat kefanaannya (mortality). Kefanaan membuat individu cemas karena ia menjadi tersadar akan kepastian kematian. Untuk menghadapi kecemasan yang diakibatkan kesadaran akan kematian, TMT memprediksi bahwa manusia akan menempuh dua cara: (1) memperkuat keyakinannya pada pandangan dunia kulturalnya dengan cara bereaksi secara positif terhadap segala hal yang mendukung pandangan dunia kulturalnya; dan (2) menyerang validitas dari pengancam pandangan dunia kultural dengan bereaksi secara negatif terhadap hal-hal yang mengancam pandangan dunia kulturalnya (Solomon, Greenberg, \& Pyszczynski, 2015). Prediksi TMT ini telah diuji oleh studi-studi empiris dengan menggunakan manipulasi eksperimental yang dinamakan saliensi mortalitas (SM) (Burke, Martens, \& Faucher, 2010).

\section{Saliensi moralitas: Bagaimana paparan terhadap kematian memengaruhi prasangka terhadap pasangan antarbudaya}

SM merupakan manipulasi eksperimental yang berupaya untuk menyadarkan seseorang akan realitas kematian. Manipulasi ini dapat dilakukan dengan beragam cara mulai dari mengarang esai mengenai kematian hingga menyaksikan cuplikan video mengenai genosida (Burke dkk., 2010). Berbagai studi telah menunjukkan bahwa manipulasi SM dapat mendorong individu untuk memperkuat identifikasinya terhadap pandangan dunia kultural yang ia anut (Greenberg dkk., 1997). Identifikasi ini dapat menimbulkan in-group bias, yang membuat individu akan cenderung menilai hal-hal terkait in-group-nya dengan lebih positif dibandingkan hal-hal terkait out-group (Harmon-Jones dkk., 1996; Tam, Chiu, \& Lau, 2007). Hal ini ditunjukkan oleh studi Greenberg, Schimel, Martens, Solomon dan Pyszcznyski (2001) yang menemukan bahwa paparan SM dapat meningkatkan dukungan partisipan berkulit putih terhadap sesama orang berkulit putih yang memiliki pandangan rasis terhadap orang berkulit hitam.

SM juga dapat mendorong individu untuk bereaksi secara lebih negatif terhadap individu atau kelompok yang menganut pandangan dunia kultural berbeda (Greenberg, Simon, Pyszczynski, Solomon, \& Chatel, 1992; Heine, Harihara, \& Niiya, 2002; McGregor dkk., 1998; Rosenblatt, Greenberg, Solomon, Pyszczynski, \& Lyon, 1989; Rothschild,
Abdollahi, \& Pyszczynski, 2009). Studi Abdollahi dkk. (2010) menunjukkan bahwa paparan SM dapat meningkatkan dukungan mahasiswa Iran terhadap penggunaan kekerasan dalam menghadapi pihak yang mengancam Islam. Seperti yang diperkirakan, paparan SM mendorong partisipan untuk memperkuat keyakinan terhadap pandangan dunia kulturalnya dan menghujat segala ancaman terhadap pandangan dunia kulturalnya. Meski demikian, beberapa studi SM pada masyarakat Asia masih belum menunjukkan hasil yang konklusif. Misalnya, studi Heine dkk. (2002) dan Tam dkk. (2007) yang menemukan adanya reaksi defensif setelah paparan SM pada partisipan warga Jepang dan Hongkong. Namun, studi Yen dan Cheng (2010) tidak menemukan reaksi defensif yang sama setelah paparan SM pada partisipan Taiwan. Adanya inkonsistensi ini dapat disebabkan oleh perbedaan saliensi dari aspek pandangan dunia kultural pada saat manipulasi SM dilakukan. Hal ini terjadi karena arah reaksi defensif pasca paparan kematian juga dapat dipengaruhi oleh aspek yang menonjol pada saat dilakukannya manipulasi SM. Seperti yang ditunjukkan oleh studi Rothschild dkk. (2009), upaya menonjolkan aspek nilai religius sebelum melakukan manipulasi SM, dapat mengubah arah dari reaksi defensif yang muncul setelah paparan kematian. Ketika partisipan dengan pandangan agama yang fundamentalis diingatkan mengenai nilai kasih sayang (compassionate values) yang ada dalam agama mereka, respons antipati mereka terhadap ancaman pandangan dunia kultural menjadi berkurang (Rothschild dkk., 2009). Untuk itu, pengujian ulang dampak SM terhadap partisipan Asia masih perlu dilakukan guna memperjelas pemahaman mengenai variasi reaksi defensif yang dapat muncul.

Adanya inkonsistensi ini juga mendorong studi ini untuk mengambil posisi konservatif dalam melakukan manipulasi SM yang akan dilakukan. Hal ini dimaksudkan untuk meningkatkan keberhasilan melakukan replikasi konseptual dengan berpedoman pada studi SM terdahulu (Burke dkk., 2010; Heine dkk., 2002). Selain itu, studi ini juga secara sengaja tidak melakukan pengukuran manipulation check-biasanya berupa pengukuran DTA (Hayes, Schimel, Arndt, \& Faucher, 2010)—hal ini dilakukan karena pengukuran DTA berpotensi mengeliminasi dampak manipulasi SM (Hayes \& Schimel, 2018).

Berbagai studi telah menunjukkan bahwa paparan SM dapat menimbulkan reaksi defensif yang mendorong individu untuk mempertahankan pandangan dunia kultural yang ia anut. Hal ini mendorong individu tersebut untuk mengukuhkan nilai-nilai yang ia anut dan bersikap antipati terhadap segala hal yang dianggap mengancam kebenaran dari nilai-nilai tersebut. Studi 
Frischlich dkk. (2015) menemukan bahwa paparan SM dapat mendorong partisipan untuk lebih memilih pasangan dari in-group. Ini berlaku selama calon pasangan dari anggota in-group tersebut memiliki banyak kesamaan (similarity) dengan partisipan yang bersangkutan. Uniknya, partisipan lebih memilih calon pasangan dari outgroup dibandingkan dissimilar in-group. Artinya anggota in-group yang tidak menunjukkan konformitas terhadap nilai atau norma in-group justru menimbulkan reaksi penolakan yang lebih besar dibandingkan anggota out-group. Ini selaras dengan hasil penelitian Arndt dkk. (2002) yang menunjukkan adanya sikap antipati yang lebih besar terhadap dissimilar in-group. Reaksi antipati ini muncul karena kehadiran dissimilar ingroup mungkin secara implisit mendorong individu terkait untuk mempertanyakan kebenaran pandangan dunia kulturalnya (Frischlich dkk., 2015). Hal ini dapat menjadi dasar bagi munculnya prasangka terhadap pasangan antarbudaya.

Bagi sebagian orang, kehadiran pasangan antarbudaya mungkin dianggap sebagai ancaman terhadap pandangan dunia kultural karena kehadiran pasangan antarbudaya - secara implisitmengindikasi adanya pelanggaran terhadap nilai pandangan dunia kultural yang dianut (dengan kata lain dissimilar in-group). Apabila benar bahwa kehadiran pasangan antarbudaya menjadi ancaman terhadap sistem manajemen teror kematian seseorang maka, dengan menyadarkan seseorang akan kematian (saliensi mortalitas), seharusnya akan memperburuk evaluasi seseorang terhadap pasangan antarbudaya.

Mengingat pasangan antarbudaya masih sering menjadi korban prasangka dan minimnya studi mengenai permasalahan ini, maka penelitian ini dilakukan guna memperoleh penjelasan mengenai permasalahan prasangka yang dihadapi pasangan antarbudaya. Dengan menggunakan perspektif TMT, penelitian ini bertujuan untuk menguji peran kecemasan eksistensial dalam kemunculan prasangka terhadap pasangan antarbudaya. Hal tersebut dilakukan dengan menguji pengaruh SM terhadap evaluasi kepada pasangan antarbudaya.

Dalam penelitian ini, adanya prasangka diindikasikan dalam bentuk tingkat evaluasi yang lebih negatif terhadap kehadiran pasangan antarbudaya. Selain itu, mengingat peran penting harga diri sebagai salah satu komponen sistem manajemen teror kematian yang dapat memengaruhi reaksi defensif yang muncul setelah paparan SM maka, tingkat harga diri partisipan juga akan diukur. Menurut TMT, harga diri merupakan manifestasi dari perasaan positif yang muncul karena telah berhasil memenuhi standar nilai pandangan dunia kultural dan memperoleh keabadian. Artinya, semakin tinggi tingkat harga diri seseorang, semakin efektif sistem manajemen teror kematian yang dimiliki orang tersebut. Maka, pengaruh defensif yang muncul setelah paparan SM mungkin akan lebih kuat pada individu yang memiliki harga diri yang rendah.

Penelitian ini juga berupaya untuk melengkapi penjelasan atas beberapa celah dari penelitian terdahulu yang terkait dengan prasangka terhadap pasangan antarbudaya (misal: Bhat, Myers, \& Royne, 2018; Skinner \& Rae, 2018). Pertama, belum ada penelitian yang membahas secara spesifik mengenai fenomena prasangka terhadap pasangan antarbudaya di Indonesia. Mayoritas penelitian terkait pasangan antarbudaya di Indonesia-biasanya berupa studi kualitatif-hanya membahas mengenai penyesuaian hidup pasangan antarbudaya. Kedua, berkenaan dengan validitas lintas budaya, penelitian yang dilakukan di luar negeri memiliki keterbatasan dalam mencerminkan realitas sosial yang dihadapi masyarakat Indonesia. Hal ini terlihat dari adanya hasil kontradiktif terkait dampak SM pada partisipan orang Asia. Ketiga, belum pernah ada penelitian yang membahas mengenai asal mula munculnya prasangka terhadap pasangan antarbudaya secara spesifik. TMT dapat menawarkan suatu penjelasan teoretis yang unik dan orisinal dalam memahami asal usul fenomena prasangka terhadap pasangan antarbudaya.

Oleh karena itu, hipotesis pertama $\left(\mathrm{H}_{1}\right)$ dari penelitian ini memprediksi bahwa partisipan yang menerima paparan kematian (SM) akan memiliki evaluasi yang lebih negatif terhadap pasangan antarbudaya dibandingkan partisipan yang tidak menerima paparan akan kematian.

Juga mengingat peran harga diri sebagai salah satu komponen lain dari sistem manajemen teror kematian maka hipotesis kedua $\left(\mathrm{H}_{2}\right)$ dari penelitian ini menduga bahwa partisipan yang memiliki harga diri yang rendah akan memiliki evaluasi yang lebih negatif terhadap pasangan antarbudaya dibandingkan partisipan yang memiliki skor harga diri tinggi.

Hipotesis terakhir $\left(\mathrm{H}_{3}\right)$ penelitian ini terkait hubungan antara SM, harga diri dan evaluasi terhadap pasangan antarbudaya yaitu: partisipan yang mendapat paparan kematian dan memiliki harga diri yang rendah akan memiliki evaluasi yang lebih negatif terhadap pasangan antarbudaya dibandingkan dengan partisipan yang tidak mendapat paparan kematian maupun partisipan yang mendapat paparan kematian dan memiliki harga diri yang tinggi.

\section{Partisipan}

\section{Metode Penelitian}

Partisipan direkrut dari mahasiswa S1 Fakultas Psikologi UI. Pengambilan data dilaku- 
kan pada sesi akhir perkuliahan kelas dengan bekerja sama dengan pengajar yang bertugas di kelas. Dengan mengacu pada estimasi effect size yang diperoleh dari studi Burke dkk. (2010) yakni $r=.35$, perhitungan $a$ priori power analysis menggunakan $G^{*}$ Power (Faul, Erdfelder, Buchner, \& Lang, 2009) menghasilkan perkiraan jumlah sampel yang dibutuhkan sebanyak 95 partisipan guna memperoleh statistical power sebesar 95\%.

\section{Desain}

Penelitian ini menggunakan desain faktorial antarsubjek (posttest only) dan berpedoman pada studi pengaruh SM terhadap bias antarkelompok terdahulu (lihat Heine, Harihara, \& Niiya, 2002). Penelitian ini membandingkan tingkat evaluasi terhadap pasangan antarbudaya pada dua kelompok yakni: (1) kelompok saliensi mortalitas vs. (2) kelompok kontrol. Partisipan pada kelompok SM diminta untuk menjawab pertanyaan terbuka mengenai kematian sedangkan partisipan pada kelompok kontrol diminta untuk menjawab pertanyaan terbuka mengenai perilaku makan. Selain itu, juga terdapat dua tugas distraksi yakni: (1) penyelesaian puzzle kata dan (2) pengisian inventori Rosenberg SelfEsteem Scale/RSES. Eksperimen berlangsung selama kurang lebih 10-15 menit pada setiap sesinya dan dilakukan di dalam ruang kelas perkuliahan. Instrumen serta prosedur penelitian telah melalui proses kaji etik oleh Komisi Etik Penelitian Psikologi UI dan telah disetujui pada tanggal 25 April 2019.

\section{Prosedur}

Setelah meminta izin kepada dosen mata ajar, peneliti masuk ke dalam ruang kelas dan menjelaskan mengenai tujuan serta durasi penelitian yang akan berlangsung (10-15 menit). Kemudian, calon partisipan diberi penjelasan bahwa penelitian yang akan dilakukan adalah tentang pengujian alat ukur kepribadian proyektif. Calon partisipan lalu diberikan kesempatan untuk mengikuti atau tidak mengikuti penelitian. Peneliti lalu menghitung jumlah partisipan dalam ruang kelas guna melakukan pembagian instrumen penelitian-antara instrumen kontrol dan instrumen MAPS - secara merata. Peneliti kemudian mempersiapkan dua kuesioner penelitian yang telah diacak sehingga baik peneliti maupun partisipan tidak mengetahui bentuk pembagian kelompok yang terjadi. Setelah kuesioner dibagikan, peneliti kemudian menjelaskan mengenai informed consent. Partisipan kemudian dipersilakan untuk mengisi informed consent dan data demografis. Setelah selesai mengisi data demografis, partisipan kemudian diminta untuk mengerjakan kuesioner secara berurutan dari instrumen SM/kontrol, word search puzzle, RSES dan terakhir mengisi evaluasi terhadap pasangan antarbudaya. Setelah selesai mengisi seluruh instrumen penelitian, partisipan kemudian diminta untuk menebak mengenai tujuan penelitian dan menuliskannya di halaman terakhir instrumen penelitian. Setelah selesai, partisipan kemudian diminta untuk mengumpulkan instrumen penelitian, peneliti kemudian melakukan debriefing dan membagikan reward.

\section{Teknik Analisis}

Ketiga hipotesis dalam studi ini diuji menggunakan two-way ANOVA 2 (SM vs. kontrol) x 2 (harga diri tinggi vs. harga diri rendah). Pengujian statistik dalam penelitian ini menggunakan $\alpha$ atau LOS sebesar .05 dan diolah menggunakan IBM SPSS versi 19.

\section{Hasil Penelitian}

\section{Gambaran Partisipan}

Sebanyak 105 mahasiswa bersedia untuk menjadi partisipan penelitian. Satu orang partisipan tidak mengisi kuesioner secara lengkap sehingga total data yang dapat diolah berjumlah 104. Sebanyak $87(83,7 \%)$ partisipan merupakan perempuan. Mayoritas partisipan berada dalam rentang usia dewasa muda dengan rerata usia $19,63(S D=1,15)$. Persebaran etnis partisipan cukup bervariasi dengan didominasi oleh etnis Jawa $(46,2 \%)$. Lebih dari separuh partisipan beragama Islam (75\%). Partisipan berasal dari angkatan yang beragam antara lain mahasiswa semester $2(22,1 \%)$, mahasiswa semester 4 $(39,4 \%)$ dan mahasiswa semester $6(38,5 \%)$.

\section{Hasil Analisis}

Hasil uji normalitas menunjukkan bentuk persebaran data yang relatif normal. Hasil uji Levene's test juga menunjukkan varians antar kelompok yang setara, $\mathrm{F}(1,102)=1,52, p=.213$. Kedua hasil tersebut memungkinkan dilakukannya analisis parametrik.

Analisis two-way ANOVA antarsubjek dilakukan untuk menguji pengaruh SM dan harga diri terhadap evaluasi kepada pasangan antarbudaya. Partisipan yang tidak diingatkan akan kematian memiliki rata-rata skor evaluasi terhadap pasangan antarbudaya yang secara signifikan lebih tinggi $(M=29,14 ; S D=5,97)$ dibandingkan partisipan yang diingatkan akan kematian $(M=27,81 ; S D=4,89), \mathrm{F}(1,100)=5,04, p=.027$, $\eta_{\mathrm{p}}{ }^{2}=.048$. Artinya, partisipan yang diingatkan akan kematian memiliki evaluasi yang relatif 
lebih negatif terhadap pasangan antarbudaya. Hal ini menunjukkan bahwa $\mathrm{H}_{1}$ studi ini didukung oleh data. Menurut (Cohen, 1988), effect size $.01<\eta_{\mathrm{p}}^{2}<.09$ tergolong small effect artinya SM memiliki dampak yang relatif kecil dalam mempengaruhi variasi skor pada evaluasi terhadap pasangan antarbudaya.

Tidak terdapat perbedaan skor rata-rata evaluasi terhadap pasangan antarbudaya yang signifikan antara partisipan yang memiliki harga diri yang tinggi $(M=28,40 ; S D=5,25)$ dengan partisipan yang memiliki harga diri yang rendah $(M=28,63 ; S D=6,18), \mathrm{F}(1,100)=.52, p=.47, \eta_{\mathrm{p}}{ }^{2}$ $=.042$. Hasil ini mensugestikan bahwa perbedaan tingkat harga diri tidak memengaruhi evaluasi terhadap pasangan antarbudaya. Dengan kata lain, $\mathrm{H}_{2}$ studi ini tidak didukung data.

Hasil uji two-way ANOVA menunjukkan adanya main effects yang signifikan antara SM dan harga diri dengan evaluasi terhadap pasangan antarbudaya, $\mathrm{F}(1,100)=4.43, p=.038, \eta_{\mathrm{p}}{ }^{2}=$ .042. Pengaruh SM terhadap evaluasi kepada pasangan antarbudaya tampak paling menonjol pada partisipan dengan tingkat harga diri yang rendah. Partisipan yang diingatkan akan kematian dan memiliki harga diri yang rendah memiliki rata-rata skor evaluasi terhadap pasangan antarbudaya yang secara signifikan jauh lebih rendah $(M=26,53 ; S D=6,05)$ dibandingkan partisipan dalam kelompok kontrol yang memiliki harga diri rendah $(M=32,11 ; S D=4,88)$. Dengan demikian, hasil tersebut mendukung $\mathrm{H}_{3}$ dari studi ini.

\section{Diskusi}

Penelitian ini merupakan studi pertama di Indonesia yang menunjukkan adanya peran kecemasan eksistensial dalam kemunculan fenomena prasangka terhadap pasangan antarbudaya. Hal ini diuji dengan menggunakan pendekatan studi saliensi mortalitas yang kerap digunakan dalam studi terror management theory. Hasil penelitian ini menunjukkan bahwa kehadiran pasangan antarbudaya dapat menjadi ancaman terhadap sistem manajemen teror kematian bagi sebagian orang. Bagi sebagian orang, kehadiran pasangan antarbudaya dianggap sebagai ancaman terhadap struktur yang memberikan stabilitas dan makna bagi kehidupan, hal ini dapat disebabkan oleh dua hal: (1) kehadiran pasangan antarbudaya mengindikasikan adanya pelanggaran terhadap nilai pandangan dunia kultural; dan (2) kehadiran pasangan antarbudaya menandakan adanya dissimilar in-group. Alhasil, kehadiran pasangan ini dapat berpotensi menimbulkan kecemasan eksistensial bagi sebagian orang.

Partisipan yang diminta untuk memikirkan mengenai kematian, memiliki skor evaluasi yang secara signifikan lebih rendah terhadap pasangan antarbudaya dibandingkan partisipan yang diminta untuk memikirkan mengenai topik netral (yakni perilaku makan). Hal ini mengindikasikan adanya upaya untuk memperkuat genggaman akan pandangan dunia kultural dengan cara menghujat atau menjatuhkan pihak yang dianggap sebagai ancaman pandangan dunia kultural tersebut. Evaluasi yang lebih negatif terhadap pasangan antarbudaya setelah paparan kematian dapat terjadi karena adanya upaya untuk mengembalikan rasa keyakinan terhadap nilai pandangan dunia kultural dan menjaga ketenangan psikologis.

\section{Gambar 1}

Pengaruh Saliensi Mortalitas dan Harga Diri terhadap Evaluasi Pasangan Antarbudaya

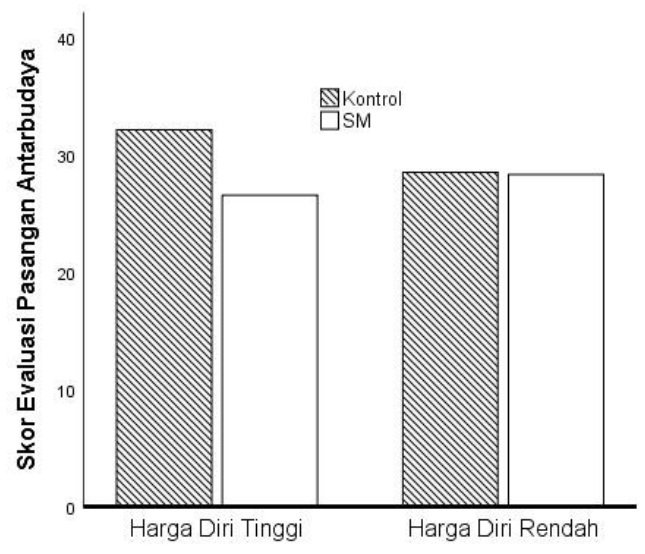


Secara implisit, studi ini juga menunjukkan bahwa dalam mengelola kecemasan eksistensial (setelah menerima paparan kematian), masyarakat Indonesia juga turut berperilaku defensif layaknya partisipan pada studi TMT pada umumnya. Hal ini konsisten dengan studi TMT yang melibatkan partisipan muslim lainnya (antara lain, Abdollahi dkk., 2010; Rothschild dkk., 2009)

Selain itu, studi ini juga menunjukkan bahwa reaksi defensif pasca paparan kematian cenderung paling menonjol pada individu yang memiliki harga diri rendah. Mengingat harga diri merupakan salah satu komponen sistem peredam kecemasan akan kematian, individu dengan harga diri yang rendah cenderung memiliki sistem peredam kecemasan akan kematian yang kurang efektif sehingga lebih rentan terhadap kecemasan eksistensial. Alhasil, ketika memperoleh paparan kematian, individu tersebut bereaksi secara lebih defensif. Di sisi lain, individu dengan harga diri yang tinggi memiliki sistem peredam kecemasan akan kematian yang cukup baik sehingga tidak menunjukkan reaksi defensif setelah paparan SM.

Singkatnya, penelitian ini menunjukkan bahwa adanya prasangka terhadap pasangan antarbudaya merupakan wujud dari upaya sebagian orang-terutama individu dengan harga diri yang rendah-untuk mengelola teror kematian mereka, yang dilakukan dengan cara menyerang secara langsung/tidak langsung pihak-pihak yang dianggap mengancam validitas pandangan dunia kultural mereka. Adanya prasangka terhadap pasangan antarbudaya karena kehadiran pasangan antarbudaya secara implisit mengancam komponen realitas simbolis yang memberikan makna dan struktur bagi kehidupan sebagian orang.

Hasil penelitian ini konsisten dengan berbagai literatur yang menunjukkan adanya pengaruh paparan kematian (SM) terhadap kemunculan prasangka kepada hal-hal yang mengancam pandangan dunia kultural (lihat Heine dkk., 2002; Rothschild dkk., 2009; Schimel dkk., 1999). Hasil penelitian ini juga menunjukkan adanya reaksi defensif setelah paparan SM pada masyarakat Indonesia. Dengan kata lain, studi ini mendukung studi-studi terdahulu yang menunjukkan kemunculan reaksi defensif pasca paparan SM pada masyarakat Asia (Heine dkk., 2002; Iqbal, O’Brien, Bliuc, \& Vergani, 2016; Tam dkk., 2007). Implikasinya, studi ini mendukung generalisasi dari TMT di masyarakat Indonesia dan menunjukkan bahwa pengaruh SM tidak hanya berlaku pada masyarakat barat saja. Dalam studi ini, reaksi defensif pasca SM paling menonjol pada partisipan dengan harga diri yang rendah. Hasil ini konsisten dengan berbagai studi yang menunjukkan adanya peran harga diri yang rendah terhadap kemunculan reaksi defensif setelah paparan SM (Gailliot, Schmeichel, \& Maner, 2007; Kashima, Halloran, Yuki, \& Kashima, 2004; Schmeichel dkk., 2009). Selain itu, hasil penelitian ini yang menunjukkan bahwa partisipan dengan harga diri yang tinggi tidak menampilkan reaksi defensif pasca paparan SM, mendukung studi yang menunjukkan adanya pengaruh protektif harga diri tinggi terhadap reaksi defensif pasca SM (Pyszczynski, Greenberg, Solomon, Arndt, \& Schimel, 2004) dan tidak mendukung studi yang menunjukkan sebaliknya (McGregor, Gailliot, Vasquez, \& Nash, 2007).

Secara luas, studi ini berupaya untuk memberikan penjelasan mengenai segala bentuk antipati dan diskriminasi yang menyasar pasangan antarbudaya. Temuan studi ini secara tidak langsung memberikan perspektif alternatif mengenai dua permasalahan yakni: (1) mengapa hubungan romantis antarbudaya bisa lebih jarang terjadi di masyarakat; dan (2) mengapa terdapat sikap antipati-misalnya, prasangka-terhadap pasangan antarbudaya yang cukup universal pada masyarakat di berbagai belahan dunia. Kecemasan eksistensial yang ditimbulkan oleh kehadiran pasangan antarbudaya mungkin memicu reaksi defensif (seperti prasangka) yang mencegah atau mempersulit terjalinnya hubungan tersebut.

Di balik segala kompleksitas dari berbagai faktor yang dapat menimbulkan prasangka terhadap pasangan antarbudaya (misalnya, faktor historis atau situasional), studi ini menawarkan adanya suatu komponen universal yang melatarbelakangi munculnya prasangka tersebut yakni upaya manusia untuk mengelola kecemasan akan kefanaannya.

\section{Kesimpulan}

Hasil penelitian menunjukkan adanya pengaruh signifikan SM terhadap evaluasi negatif kepada pasangan antarbudaya. Partisipan yang diminta untuk memikirkan mengenai kematian memiliki skor rata-rata evaluasi terhadap pasangan antarbudaya yang secara signifikan lebih rendah dibandingkan partisipan yang diminta untuk memikirkan mengenai perilaku makan.

Perbedaan tingkat harga diri tidak memengaruhi evaluasi terhadap pasangan antarbudaya. Dengan kata lain, tidak terdapat perbedaan skor rata-rata evaluasi terhadap pasangan antarbudaya yang signifikan antara partisipan yang memiliki harga diri tinggi dengan partisipan yang memiliki harga diri rendah.

Partisipan dengan harga diri rendah dan diingatkan akan kematian memiliki tingkat evaluasi yang secara signifikan lebih rendah terhadap pasangan antarbudaya dibandingkan partisipan pada tiga kelompok lainnya yakni partisipan yang memiliki harga diri tinggi dan diingatkan 
akan kematian (SM dan harga diri tinggi), partisipan yang memiliki harga diri tinggi dan tidak diingatkan akan kematian (kontrol dan harga diri tinggi) maupun partisipan yang memiliki harga diri rendah yang tidak diingatkan akan kematian (kontrol dan harga diri rendah).

\section{Keterbatasan dan Saran}

Penelitian ini memiliki beberapa keterbatasan. Pertama, pengukuran prasangka pada penelitian ini hanya dilakukan untuk out-group derogation dan mengabaikan komponen lain dari intergroup bias yakni in-group favoritism (Hewstone, Rubin, \& Wilis, 2002). Penelitian selanjutnya diharapkan dapat mengikutsertakan pengukuran in-group favoritism (seperti dengan meminta partisipan untuk mengevaluasi pasangan sama budaya) agar dapat memperoleh gambaran komposit intergroup bias seperti dalam studi Park dan Pyszczynski (2019).

Kedua, manipulasi SM dalam penelitian ini tidak disertai dengan manipulation check sehingga tidak diketahui secara pasti apakah manipulasi SM yang dilakukan berhasil meningkatkan pikiran tak sadar mengenai kematian (DTA). Dalam studi ini, pengukuran DTA sebagai manipulation check sengaja tidak dilakukan karena muncul kekhawatiran bahwa ini dapat menghilangkan reaksi defensif pasca paparan kematian (Hayes \& Schimel, 2018). Manipulasi SM dan pengukuran DTA pada studi yang sama mungkin menjadi alasan mengapa beberapa studi SM yang melakukan dua hal tersebut pada sesi eksperimen yang sama gagal menemukan reaksi defensif pengaruh paparan kematian (Agroskin \& Jonas, 2013). Namun, studi Park dan Pyszczynski (2019) melakukan manipulasi SM dan DTA pada sesi yang sama dan ternyata berhasil menemukan peran moderasi dari DTA terhadap reaksi defensif pasca manipulasi SM. Karena tidak dilakukan usaha pengukuran DTA, sulit untuk mengetahui secara pasti apakah reaksi defensif-berupa evaluasi negatif terhadap pasangan antarbudaya-yang muncul setelah paparan kematian merupakan upaya untuk mengelola pikiran-pikiran tak sadar mengenai kematian. Untuk itu, penelitian selanjutnya disarankan melakukan pengukuran DTA menggunakan metode experimentalcausal-chain yang disarankan oleh Hayes dan Schimel (2018).

Ketiga, dalam penelitian ini, pengukuran harga diri dan prasangka dilakukan menggunakan self-report yang dapat terkontaminasi oleh social desirability bias. Untuk menutupi kelemahan ini, studi selanjutnya dapat melakukan pengukuran harga diri secara implisit (Schmeichel dkk., 2009) maupun pengukuran implicit attitude test (Greenwald, McGhee, \& Schwartz, 1998). Dengan adanya berbagai limitasi tersebut, interpretasi dan generalisasi dari hasil penelitian ini harus dilakukan dengan berhati-hati. Oleh karena itu, upaya untuk melakukan replikasi penelitian ini juga sangat direkomendasikan.

Walaupun ada berbagai keterbatasan, penelitian ini berkontribusi terhadap pemahaman mengenai fenomena prasangka terhadap pasangan antarbudaya. Hasil penelitian ini menunjukkan adanya peran kecemasan eksistensial dalam kemunculan prasangka terhadap pasangan antarbudaya. Oleh karena itu, ada tiga saran praktis yang dapat dilakukan untuk mengurangi prasangka yang ditimbulkan kecemasan eksistensial tersebut.

Pertama, menekankan pada aspek pandangan dunia kultural yang mempromosikan nilai-nilai perdamaian (Greenberg, Landau, Kosloff, Soenke, \& Solomon, 2016). Berbagai studi telah menunjukkan bahwa memanipulasi saliensi nilai religius (Rothschild dkk., 2009), nilai toleransi (Greenberg dkk., 1992), atau mindfulness (Park \& Pyszczynski, 2019) dapat mengurangi reaksi defensif pasca paparan kematian. Mengingat reaksi defensif yang muncul setelah paparan kematian sangat dipengaruhi oleh aspek saliensi dari pandangan dunia kultural yang ada maka, dengan memanipulasi saliensi konten yang ada pada pandangan dunia kultural, prasangka yang muncul sebagai akibat upaya meredam kecemasan akan kematian dapat dikurangi.

Kedua, melakukan manipulasi konsensus dengan cara mempromosikan nilai-nilai bahwa hubungan romantis antarbudaya merupakan hal yang umum. Hal ini didasari oleh studi Abdollahi dkk. (2010) yang menunjukkan bahwa manipulasi (priming) konsensus dapat mengeliminasi reaksi defensif setelah paparan SM.

Terakhir, Greenberg, dkk. (2016) menjelaskan bahwa salah satu tantangan terbesar dalam memerangi prasangka ada pada upaya mendidik generasi muda yakni terkait bagaimana kita dapat mendidik dan membesarkan anak-anak dengan nilai toleransi, kemanusiaan, pandangan dunia yang tidak hitam-putih, harga diri yang kokoh, serta cara yang efektif dalam menghadapi kecemasan eksistensial. Dengan demikian penelitian ini juga menunjukkan bukan kematian yang memisahkan kita. Prasangkalah yang memisahkan kita.

\section{Daftar Pustaka}

Abdollahi, A., Henthorn, C., \& Pyszczynski, T. (2010). Experimental peace psychology: Priming consensus mitigates aggression against outgroups under mortality salience. Behavioral Sciences of Terrorism and Political Aggression, 2(1), 
30-37.

https://doi.org/10.1080/19434470903 319466

Agroskin, D., \& Jonas, E. (2013). Controlling death by defending ingroups - Mediational insights into terror management and control restoration. Journal of Experimental Social Psychology, 49(6), 1144-1158.

https://doi.org/10.1016/j.jesp.2013.05. 014

Arndt, J., Greenberg, J., Schimel, J., Pyszczynski, T., \& Solomon, S. (2002). To belong or not to belong, that is the question: Terror management and identification with gender and ethnicity. Journal of Personality and Social Psychology, 83(1), 26-43. https://doi.org/10.1037//00223514.83.1.26

Bhat, S., Myers, S., \& Royne, M. (2018). Interracial couples in ads: Do consumers' gender and racial differences affect their reactions? Journal of Current Issues \& Research in Advertising, 39(2), 160-177. https://doi.org/10.1080/10641734.20 18.1428249

Biever, J. L., Bobele, M., \& North, M.-W. (1998). Therapy with intercultural couples: A postmodern approach. Counselling Psychology Quarterly, 11(2), 181-188. https://doi.org/10.1080/09515079808 254053

Burke, B. L., Martens, A., \& Faucher, E. H. (2010). Two decades of terror management theory: A meta-analysis of mortality salience research. Personality and Social Psychology Review, 14(2), 155-195. https://doi.org/10.1177/10888683093 52321

Cohen, J. (1988). Statistical power analysis for the behavioral sciences (2nd ed). Hillsdale, N.J: L. Erlbaum Associates.

Djamba, Y. K., \& Kimuna, S. R. (2014). Are Americans really in favor of interracial marriage? A closer look at when they are asked about black-white marriage for their relatives. Journal of Black Studies, 45(6), 528-544. https://doi.org/10.1177/00219347145 41840

Faul, F., Erdfelder, E., Buchner, A., \& Lang, A.-G. (2009). Statistical power analyses using G*Power 3.1: Tests for correlation and regression analyses. Behavior Research Methods, 41(4), 1149-1160. https://doi.org/10.3758/BRM.41.4.114 9

Frischlich, L., Rieger, D., Dratsch, T., \& Bente, G. (2015). Meet Joe Black? The effects of mortality salience and similarity on the desire to date in-group versus out-group members online. Journal of Social and Personal Relationships, 32(4), 509-528. https://doi.org/10.1177/02654075145 36305

Gailliot, M. T., Schmeichel, B. J., \& Maner, J. K. (2007). Differentiating the effects of selfcontrol and self-esteem on reactions to mortality salience. Journal of Experimental Social Psychology, 43(6), 894-901.

https://doi.org/10.1016/j.jesp.2006.10. 011

Greenberg, J., Landau, M. J., Kosloff, S., Soenke, M., \& Solomon, S. (2016). How our means for feeling transcendent of death foster prejudice, stereotyping, and intergroup conflict: Terror management theory. In T. D. Nelson (Ed.), Handbook of prejudice, stereotyping, and discrimination (2nd ed., pp. 107-148). New York, NY, US: Psychology Press.

Greenberg, J., Pyszczynski, T., \& Solomon, S. (1986). The causes and consequences of a need for self-esteem: A terror management theory. In R. F. Baumeister (Ed.), Public self and private self (pp. 189-212). https://doi.org/10.1007/978-1-46139564-5_10

Greenberg, J., Schimel, J., Martens, A., Solomon, S., \& Pyszcznyski, T. (2001). Sympathy for the devil: Evidence that reminding whites of their mortality promotes more favorable reactions to white racists. Motivation and Emotion, 25(2), 113-133. https://doi.org/10.1023/A:101061390 9207

Greenberg, J., Simon, L., Pyszczynski, T., Solomon, S., \& Chatel, D. (1992). Terror management and tolerance: Does mortality salience always intensify negative reactions to others who threaten one's worldview? Journal of Personality and Social Psychology, 63(2), 212-220.

Greenberg, J., Solomon, S., \& Pyszczynski, T. (1997). Terror management theory of self-esteem and cultural worldviews: Empirical assessments and conceptual refinements. In M. P. Zanna (Ed.), Advances in experimental social psychology (Vol. 29, pp. 61-139). https://doi.org/10.1016/S00652601(08)60016-7

Greenwald, A. G., McGhee, D. E., \& Schwartz, J. L. K. (1998). Measuring individual differences in implicit cognition: The 
implicit association test. Journal of Personality and Soclal Psychology, 74(6), 1464-1480.

https://doi.org/10.1037/0022-

3514.74.6.1464

Harmon-Jones, E., Greenberg, J., Solomon, S., \& Simon, L. (1996). The effects of mortality salience on intergroup bias between minimal groups. European Journal of Social Psychology, 26(4), 677-681. https://doi.org/10.1002/(SICI)10990992(199607)26:4<677::AIDEJSP777>3.0.CO;2-2

Hayes, J., Schimel, J., Arndt, J., \& Faucher, E. H. (2010). A theoretical and empirical review of the death-thought accessibility concept in terror management research. Psychological Bulletin, 136(5), 699-739. https://doi.org/10.1037/a0020524

Hayes, J., \& Schimel, J. (2018). Unintended effects of measuring implicit processes: The case of death-thought accessibility in mortality salience studies. Journal of Experimental Social Psychology, 74, 257269.

https://doi.org/10.1016/j.jesp.2017.10. 005

Heine, S. J., Harihara, M., \& Niiya, Y. (2002). Terror management in Japan: Terror management in Japan. Asian Journal of Social Psychology, 5(3), 187-196. https://doi.org/10.1111/1467839X.00103

Hewstone, M., Rubin, M., \& Wilis, H. (2002). Intergroup Bias. Annual Review of Psychology, 53, 575-604. https://doi.org/10.1146/annurev.psyc h.53.100901.135109

Iqbal, M., O’Brien, K. S., Bliuc, A.-M., \& Vergani, M. (2016). Death reminders increase agreement with extremist views but not violent extremist action in Indonesian muslims. Journal of Cross-Cultural Psychology, 47(6), 891-897. https://doi.org/10.1177/00220221166 46875

Juhl, J., \& Routledge, C. (2016). Putting the terror in terror management theory: Evidence that the awareness of death does cause anxiety and undermine psychological well-being. Current Directions in Psychological Science, 25(2), 99-103. https://doi.org/10.1177/09637214156 25218

Kashima, E. S., Halloran, M., Yuki, M., \& Kashima, Y. (2004). The effects of personal and collective mortality salience on individualism: Comparing Australians and Japanese with higher and lower self- esteem. Journal of Experimental Social Psychology, 40(3), 384-392. https://doi.org/10.1016/j.jesp.2003.07. 007

McGregor, H. A., Lieberman, J. D., Greenberg, J., Solomon, S., Arndt, J., Simon, L., \& Pyszczynski, T. (1998). Terror management and aggression: Evidence that mortality salience motivates aggression against worldviewthreatening others. Journal of Personality and Social Psychology, 74(3), 590-605.

https://doi.org/10.1037/00223514.74.3.590

McGregor, I., Gailliot, M. T., Vasquez, N. A., \& Nash, K. A. (2007). Ideological and personal zeal reactions to threat among people with high self-esteem: Motivated promotion focus. Personality and Social Psychology Bulletin, 33(11), 1587-1599. https://doi.org/10.1177/01461672073 06280

Park, Y. C., \& Pyszczynski, T. (2019). Reducing defensive responses to thoughts of death: Meditation, mindfulness, and Buddhism. Journal of Personality and Social Psychology, 116(1), 101-118. https://doi.org/10.1037/pspp0000163

Pyszczynski, T., Greenberg, J., Solomon, S., Arndt, J., \& Schimel, J. (2004). Why do people need self-esteem? A theoretical and empirical review. Psychological Bulletin, 130(3), 435-468. https://doi.org/10.1037/00332909.130.3.435

Pyszczynski, T., Solomon, S., \& Greenberg, J. (2015). Thirty years of terror management theory. In M. P. Zanna \& J. Olson (Eds.), Advances in experimental social psychology (Vol. 52, pp. 1-70). https://doi.org/10.1016/bs.aesp.2015. 03.001

Rosenblatt, A., Greenberg, J., Solomon, S., Pyszczynski, T., \& Lyon, D. (1989). Evidence for terror management theory: I. The effects of mortality salience on reactions to those who violate or uphold cultural values. Journal of Personality and Social Psychology, 57(4), 681-690. https://doi.org/10.1037/00223514.57.4.681

Rothschild, Z. K., Abdollahi, A., \& Pyszczynski, T. (2009). Does peace have a prayer? The effect of mortality salience, compassionate values, and religious fundamentalism on hostility toward outgroups. Journal of Experimental Social Psychology, 45(4), 816-827. 
https://doi.org/10.1016/j.jesp.2009.05. 016

Schimel, J., Simon, L., Greenberg, J., Pyszczynski, T., Solomon, S., Waxmonsky, J., \& Arndt, J. (1999). Stereotypes and terror management: Evidence that mortality salience enhances stereotypic thinking and preferences. Journal of Personality and Social Psychology, 77(5), 905-926. https://doi.org/10.1037/00223514.77.5.905

Schmeichel, B. J., Gailliot, M. T., Filardo, E.-A., McGregor, I., Gitter, S., \& Baumeister, R. F. (2009). Terror management theory and self-esteem revisited: The roles of implicit and explicit self-esteem in mortality salience effects. Journal of Personality and Social Psychology, 96(5), 1077-1087.

https://doi.org/10.1037/a0015091

Skinner, A. L., \& Hudac, C. M. (2017). "Yuck, you disgust me!" Affective bias against interracial couples. Journal of Experimental Social Psychology, 68, 6877.

https://doi.org/10.1016/j.jesp.2016.05. 008

Skinner, A. L., \& Rae, J. R. (2018). A robust bias against interracial couples among white and black respondents, relative to multiracial respondents. Social Psychological and Personality Science, 194855061878371.

https://doi.org/10.1177/19485506187 83713

Solomon, S., Greenberg, J., \& Pyszczynski, T. (2015). The worm at the core. New York, NY: Random House.

Tam, K.-P., Chiu, C.-Y., \& Lau, I. Y.-M. (2007). Terror management among Chinese: Worldview defence and intergroup bias in resource allocation. Asian Journal of Social Psychology, 10(2), 93-102. https://doi.org/10.1111/j.1467839X.2007.00216.X

Yen, C.-L., \& Cheng, C.-P. (2010). Terror management among Taiwanese: Worldview defence or resigning to fate?: Terror management among Taiwenese. Asian Journal of Social Psychology, 13(3), 185-194.

https://doi.org/10.1111/j.1467839X.2010.01328.x

Yulianto, J. E., \& Faturochman, F. (2017). The Impact of Interethnic Marital Relation on the Dynamics of Interdependence: A Phenomenological Finding from Javanese and Chinese Couples in Indonesia. Hubs-Asia, 10(1), 88-100. doi: 10.7454/mssh.v20i2.463 